\title{
AUDIODESCRIÇÃO SIMULTÂNEA: PROPOSTAS METODOLÓGICAS E PRÁTICAS
}

\author{
SIMULTANEOUS AUDIO DESCRIPTION: \\ METHODOLOGICAL AND PRACTICAL PROPOSALS
}

\author{
Soraya Ferreira Alves* \\ Veryanne Couto Teles*
}

\section{RESUMO}

As mudanças que a sociedade brasileira vem sofrendo nas últimas décadas ajudaram a aumentar a conscientização sobre a importância da inclusão de grupos sociais historicamente marginalizados. Esse processo de ampliação da acessibilidade e seus mecanismos faz parte do crescente esforço para integrar uma parcela importante da população: as pessoas com deficiência. A audiodescrição (AD), assim como outras formas de tradução audiovisual (TAV), desempenha papel importante na promoção da acessibilidade, já que é uma ferramenta de tecnologia assistiva imprescindível para desenvolvimento social e por isso mesmo vem ganhando destaque. Por outro lado, para a consolidação satisfatória da aplicação da $\mathrm{AD}$ no país, são necessárias pesquisas que abordem essa mediação tradutória em diferentes ambientes. Sendo assim, este trabalho visa apresentar uma proposta de modelo de pré-roteiro para audiodescrição simultânea (ADS) embasada em aspectos teóricos da $\mathrm{AD}$ e na análise da própria prática das autoras.

Palavras-chave: tradução; audiodescrição simultânea; acessibilidade.

\section{ABSTRACT}

The changes that Brazilian society has undergone in recent decades helped raise the awareness about the importance of inclusion of social groups historically marginalized. This accessibility enlargement process and its mechanisms is part of the growing effort to integrate a significant portion of the population: people with disabilities. The audiodescription (AD) and other forms of audiovisual translation, plays an important role in promoting accessibility, since it is an assistive technology tool essential for social development and therefore is gaining prominence. Moreover, for satisfactory consolidation of the application of $\mathrm{AD}$ in the country, research is needed to address this translational mediation in different environments. Thus, this work aims at presenting a proposal for pre-script template for simultaneous audio description (ADS) grounded in theoretical aspects of AD and in the analysis of the practice of these authors.

Keywords: translation; simultaneous audio description; accessibility.

\footnotetext{
* Universidade de Brasília, Brasília DF. Brasil.so.ferreira@uol.com.br

** Secretaria de Estado de Educação do Distrito Federal, Brasília DF. Brasil, veryanne@gmail.com
} 


\section{INTRODUÇÃO}

A audiodescrição (AD) é uma modalidade da tradução que vem ganhando reconhecimento com o avanço das tecnologias assistivas e com a tomada de consciência da sociedade acerca das pessoas com deficiência. No entanto, apesar do crescente número de pesquisas, são poucas as que tratam especificamente da audiodescrição simultânea (ADS).

A partir da própria experiência das autoras e na perspectiva de sistematizar uma metodologia para auxiliar essa prática, foram elaboradas sugestões para um modelo de pré-roteiro de audiodescrição a ser adotado na audiodescrição simultânea, bem como uma metodologia para a audiodescrição de eventos ao vivo.

Assim sendo, este trabalho busca investigar as particularidades da ADS a fim de contribuir para a elaboração de um modelo de AD que possa ajudar na prática e formação de audiodescritores no Brasil. Para isso, abordamos aqui a relação entre a acessibilidade e a audiodescrição, fazemos um histórico do desenvolvimento desta última, refletindo sobre sua repercussão em âmbito geral, nacional e científico. Falamos também da classificação dessa modalidade tradutória para enfocar especificamente a audiodescrição simultânea e propomos um método para sua aplicação.

\section{AUDIODESCRIÇÃO E ACESSIBILIDADE: PANORAMA GERAL}

A acessibilidade é uma questão ampla que pode ser definida de diferentes formas e envolve uma variada gama de conceitos. Fala-se de acessibilidade atitudinal, arquitetônica, comunicacional, instrumental, metodológica e programática (SASSAKI, 2009). O que todas têm em comum é a ideia básica da busca pelo acesso igualitário de diferentes pessoas (pessoas com ou sem deficiência, mobilidade reduzida, idosos, entre outros) a todos os espaços da sociedade, entendendo que indivíduos com características e habilidades diversas requerem modelos e intervenções que estejam de acordo com essa diversidade.

No processo de desenvolvimento histórico, o homem social modifica os meios e os procedimentos de seu comportamento, transformando as atitudes e funções naturais e construindo novos níveis no sistema de comportamento (VIGOTSKY, 1989, p. 93). Os meios sociais e culturais são então muito importantes para o desenvolvimento humano e as relações do sujeito versus outros (pais, irmãos, colegas, professores) são essenciais para o pleno alcance do bem-estar do indivíduo. 
Dessa forma, qualquer pessoa deve dispor dos mais diversos ambientes, serviços e produtos - sejam eles físicos ou virtuais - em igualdade de condições e de forma a serem utilizados com conforto e segurança.

A Lei Brasileira de Inclusão - LEI N ${ }^{\circ}$ 13.146, de 6 de julho de 2015 representa novo marco sobre as questões envolvendo a igualdade e a isonomia para a cidadania brasileira. O tema ganhou tamanha relevância que foi inserido na legislação brasileira de forma a exigir de todos os atores a execução de seus comandos legais, como pode ser exemplificado na breve seleção de artigos abaixo relacionados:

Art. 67. Os serviços de radiodifusão de sons e imagens devem permitir o uso dos seguintes recursos, entre outros:

I - subtitulação por meio de legenda oculta;

II - janela com intérprete da Libras;

III - audiodescrição.

Art. 70. As instituições promotoras de congressos, seminários, oficinas e demais eventos de natureza científico-cultural devem oferecer à pessoa com deficiência, no mínimo, os recursos de tecnologia assistiva previstos no art. 67 desta Lei.

Art. 71. Os congressos, seminários, oficinas e demais eventos científicoculturais promovidos ou financiados pelo poder público devem garantir as condições de acessibilidade e os recursos de tecnologia assistiva. ${ }^{1}$

Pode-se dizer, então, que a audiodescrição como ferramenta para a promoção da acessibilidade e inclusão de pessoas com deficiência visual é um elemento imprescindível na sociedade contemporânea. As tecnologias assistivas têm contribuído para que a audiodescrição seja uma modalidade de relevância tanto no ambiente acadêmico quanto na prática profissional, uma vez que a relação entre tradução e acessibilidade vem ganhando espaço cada vez maior nas discussões e pesquisas sobre tradução audiovisual. A sociedade precisa se adaptar às novas demandas que surgem a cada dia e o tradutor precisa ter uma formação adequada ao tipo de produto que lhe é demandado, bem como ter consciência do público específico ao qual ele se direciona, sempre se atualizando e profissionalizando. Dessa forma, a sociedade precisa propiciar as condições necessárias que garantam

1. Disponível em: http://www.planalto.gov.br/CCIVIL_03/_Ato2015-2018/2015/Lei/L13146.htm Acesso em 05/11/2016. 
a autonomia dos cidadãos para que possam exercer livremente seus direitos. Assim, como explica Vigata (2016),

[...] todas as barreiras físicas e virtuais que impeçam o exercício de nossos direitos devem ser eliminadas, começando pelas barreiras comunicacionais, já que, se uma pessoa não consegue ter acesso à informação e à comunicação, também ficará impedida de exercer outros direitos fundamentais nas áreas de educação, cultura, saúde, justiça, trabalho e vida política, entre outros. (VIGATA, 2016, p. 39)

Nesse sentido, a audiodescrição ajuda a romper a barreira comunicacional no que tange às pessoas com deficiência visual, sendo comunicação o que abrange, pela Convenção sobre os Direitos da Pessoa com Deficiência,

[...] as línguas, a visualização de textos, o Braile, a comunicação tátil, os caracteres ampliados, os dispositivos de multimídia acessível, assim como a linguagem simples, escrita e oral, os sistemas auditivos e os meios de voz digitalizada e os modos, meios e formatos aumentativos e alternativos de comunicação, inclusive tecnologia da informação e comunicação acessíveis. (CDPD, 2011, p. 24)

A AD é considerada uma modalidade de tradução audiovisual e se insere na área dos Estudos da Tradução, pois, segundo Diaz-Cintas (2007),

[o] termo tradução audiovisual tem sido usado como conceito global que encapsula as diferentes práticas tradutórias que se implementam nos meios audiovisuais na hora de se traduzir uma mensagem de uma língua para outra e em um formato em que haja uma interação semiótica entre o som e as imagens. ${ }^{2}$ (DIAZ-CINTAS, 2007, p.18)

A AD tem como objeto a descrição verbal de imagens. Ela é utilizada em diversos meios como cinema, televisão, no teatro, em conferências, eventos culturais e para obras de arte. O interesse pela TAV no âmbito dos Estudos da Tradução ganhou impulso na década de 1980, atingindo seu auge na década de 1990. A partir do ano 2000, especificamente no Brasil, a tradução audiovisual ganhou maior visibilidade por conta das leis que garantem acessibilidade de informação e comunicação às pessoas com deficiência. A partir de então, não apenas a legenda fechada e a dublagem ganharam ainda mais destaque, mas também a legendagem para surdos e ensurdecidos (LSE), a audiodescrição (AD) e a interpretação em Língua de Sinais - LIBRAS.

A AD será entendida aqui como tradução intersemiótica. Parafraseando Roman Jakobson (1995), a tradução engloba outras modalidades que não somente

2. Do original: El término "traducción audiovisual" se ha venido usado como concepto global que encapsula las diferentes practicas traductoras que se implementan en los medios audiovisuals a la hora de transvasar un mensaje de una lengua a outra, en un format en el que hay una interacción semiótica entre el sonido y las imágenes". Esta e todas as traduções não referenciadas são nossas. 
a tradução interlingual (ou "propriamente dita"), como a tradução intersemiótica, que seria "interpretação de signos verbais por meio de sistemas de signos nãoverbais" (JAKOBSON, 1995, p. 65). No caso da AD, esta pode ser considerada uma transmutação de signos não verbais (imagens) para signos verbais (roteiro e narração). Julio Plaza (1987) expande a definição de tradução intersemiótica, pois a define como uma operação na qual um texto pertencente a um sistema de signos (verbais, sonoros, visuais, etc.) é traduzido para outro sistema de signos diferente. $\mathrm{A} A \mathrm{D}$, sendo uma transmutação de signos não verbais (imagens) para signos verbais (roteiro e narração) é, portanto, não só uma forma de TAV como também uma modalidade de tradução intersemiótica.

Por isso a AD pode ser definida como:

[...] um recurso de acessibilidade que amplia o entendimento das pessoas com deficiência visual em eventos culturais, gravados ou ao vivo, como: peças de teatro, programas de TV, exposições, mostras, musicais, óperas, desfiles e espetáculos de dança; eventos turísticos, esportivos, pedagógicos e científicos tais como aulas, seminários, congressos, palestras, feiras e outros, por meio de informação sonora. É uma atividade de mediação linguística, uma modalidade de tradução intersemiótica (JAKOBSON, 1995) que transforma o visual em verbal, abrindo possibilidades maiores de acesso à cultura e à informação, contribuindo para a inclusão cultural, social e escolar. Além das pessoas com deficiência visual, a audiodescrição amplia também o entendimento de pessoas com deficiência intelectual, idosos e disléxicos". (MOTTA $;$ ROMEU FILHO, 2010, p. 11)

A fim de compreender o fenômeno da acessibilidade de produtos visuais advindos e decorrentes da audiodescrição, é necessário conhecer essa modalidade de tradução e suas implicações, bem como elementos e teorias a ela correlacionadas.

Devemos tratar, então, a audiodescrição como uma atividade de mediação linguística e uma modalidade de tradução intersemiótica, bem como a técnica utilizada para tornar o teatro, o cinema, a $\mathrm{TV}$, obras de arte visuais, ou seja, qualquer ambiente social e cultural acessível a pessoas com deficiência visual, contribuindo para sua inclusão e interação sociocultural. As intervenções são inseridas entre os diálogos em produtos audiovisuais e não interfere nos efeitos musicais e sonoros. No caso de obras de artes plásticas (pintura, escultura), ocorre a tradução dos aspectos da obra como composição das telas ou técnicas utilizadas. A AD pode ser gravada ou feita ao vivo, seguindo um roteiro pré-definido ou de maneira totalmente simultânea.

A noção da $\mathrm{AD}$ como tradução é essencial para seu reconhecimento como trabalho intelectual. O governo federal reconheceu essa modalidade quando definiu a AD no Projeto de Lei n ${ }^{\circ} 5.156$ de 2013, artigo $1^{\circ}$, Parágrafo único como: 
[...] um instrumento tradutório de acessibilidade comunicacional que consiste no conjunto de técnicas e habilidades aplicadas, com objetivo de proporcionar uma narração descritiva em áudio para ampliação do entendimento, de imagens estáticas ou dinâmicas, textos e origem de sons, despercebidos ou incompreensíveis especialmente sem o uso da visão.

Segundo Franco \& Silva (2010, p. 23-42), foi em 1981 que a audiodescrição surgiu de fato, como resultado do trabalho de Margaret e Cody Pfanstiehl, que fundam um serviço de audiodescrição para peças de teatro no Arena Stage Theater, em Washington DC. No Brasil, a audiodescrição foi utilizada em público, pela primeira vez, em 2003, durante o festival temático Assim Vivemos: Festival Internacional de Filmes sobre Deficiência. Nos anos seguintes foram sendo formados grupos de pesquisa, consultas públicas juntamente com o Ministério das Comunicações, Ancine e sociedade, em busca da legalização da AD e da sua aplicabilidade. Com o tempo, a audiodescrição foi ganhando forma e força com a produção de DVDs acessíveis, mostras de cinema, espetáculos teatrais e de dança, museus e em eventos, principalmente governamentais.

Contudo, segundo Diaz-Cintas, a tradução como modalidade de acessibilidade, bem como o tradutor que dela se ocupa, ainda precisam ser mais bem conceituados e entendidos em seu meio de trabalho:

Falamos de "acessibilidade", mas carecemos de um conceito geral que aglutine os responsáveis encarregados desta, contrariamente ao que acontece no terreno da tradução (tradutor) e da interpretação (intérprete). Dado o impulso atual desta nova atividade social e profissional e suas boas perspectivas de futuro, talvez seja o momento adequado de cunhar um novo termo e começar a falar da figura do "acessibilitador", como especialista último no terreno da acessibilidade. $^{3}$ (DÍAZ CINTAS, 2007, p. 46)

\section{CLASSIFICAÇÕES E ESTRUTURA DA AUDIODESCRIÇÃO}

A AD vai muito além da descrição de informações percebidas pela visão. Questões técnicas, linguísticas e de gênero precisam ser observadas (BARBOSA, 2012). É preciso levar em consideração uma série de fatores relacionados à obra ou ao evento a ser audiodescrito, ao tipo de $\mathrm{AD}$ que será realizada e ao público alvo. Segundo Alves e Teixeira (2015),

3. "Hablamos de «accesibilidad», pero carecemos de un concepto general que aglutine a los responsables encargados de la misma, contrariamente a lo que ocurre en el terreno de la traducción (traductor) y la interpretación (intérprete). Dado el empuje actual de esta nueva actividad social y profesional y sus buenas perspectivas de futuro, quizá sea el momento adecuado de acuñar un nuevo término y empezar a hablar de la figura del «accesibilitador», como experto último en el terreno de la accesibilidad". 
Não basta apenas descrever o que se vê, mas sim o que é importante para a construção semiótica da obra. A audiodescrição não é um elemento que participa da construção do significado na elaboração de uma obra; mas, quando colocada junto à esta, passa a ser elemento de composição do significado para quem se utiliza dela. (ALVES e TEIXEIRA, 2015, p. 171)

Como as características de cada modalidade de $\mathrm{AD}$ estão relacionadas às particularidades de cada obra ou evento, é necessário entender as diferenças que isso produz e como impacta em uma classificação. Costa \& Frota (2011) classificou os tipos de AD levando em conta dois aspectos: (i) a natureza do objeto a ser descrito e (ii) a simultaneidade da elaboração do roteiro e da execução da narração. Segundo as autoras, as imagens podem ser estáticas ou dinâmicas e, a depender das circunstâncias, serem audiodescritas por meio de gravação (com preparação do roteiro e narração gravada antes do evento), ao vivo (com preparação antecipada do roteiro e narração no momento do evento), ou de forma simultânea (sem a preparação do roteiro e com a narração no exato momento do evento)

\begin{tabular}{|c|c|c|c|}
\hline Tipo & Roteiro & Narração & Exemplos \\
\hline Gravada & Antes da exibição & Antes da exibição & $\begin{array}{l}\text { Programas de TV pré- } \\
\text { produzidos, cinema, etc. }\end{array}$ \\
\hline Ao vivo & Antes da exibição & $\begin{array}{l}\text { No momento da } \\
\text { exibição }\end{array}$ & $\begin{array}{c}\text { Programas de TV ao vivo, } \\
\text { peças de teatro, visitas a } \\
\text { museu, etc. }\end{array}$ \\
\hline Simultânea & $\begin{array}{l}\text { No momento da } \\
\text { exibição }\end{array}$ & $\begin{array}{l}\text { No momento da } \\
\text { exibição }\end{array}$ & $\begin{array}{l}\text { Notícias de última hora, } \\
\text { paradas, eventos esportivos, } \\
\text { etc. }\end{array}$ \\
\hline \multicolumn{4}{|c|}{ Fonte: Adaptado de Costa \& Frota, 2011.} \\
\hline
\end{tabular}

Sendo assim, na AD gravada o roteiro e a narração são preparados antes da exibição, isto é, antes do momento em que é "consumida" pela audiência, enquanto na $\mathrm{AD}$ ao vivo o roteiro é elaborado antecipadamente, mas a narração é feita no momento do evento. Já na AD simultânea é praticamente impossível preparar algum roteiro antecipadamente $\mathrm{e}$, portanto, a audiodescrição ocorre integralmente no momento do evento: roteiro e narração em ato único e em tempo real no transcorrer da ação, sendo o audiodescritor um narrador/roteirista simultâneo.

Independentemente do tipo de $\mathrm{AD}$, não existem regras rígidas e imutáveis, por isso, como toda tradução, elas precisam ser sempre relativizadas. Contudo, mesmo para a ADS, seguir as orientações de práticas já testadas facilita e colabora para o sucesso do trabalho dos audiodescritores. 


\section{AUDIODESCRIÇÃO COMO TIPO TEXTUAL}

O audiodescritor (ADR), quando faz o roteiro, deve estar consciente de que a AD é um tipo textual com características concretas e próprias, como afirma Posadas (2008), que dão ao texto uma nova dimensão tradutória. A tarefa de audiodescrever requer também uma investigação sobre o material a ser audiodescrito como, por exemplo, a cinematografia, estudos da semiótica, gênero, público, entre outros.

Se a audiodescrição não atender à máxima coerência, coesão, intencionalidade, aceitabilidade, contextualização, intertextualidade e informatividade, não pode ser considerada um texto - de fato, não está de acordo com uma lógica de causa-efeito, mas mantém coerência com diálogos, imagens e referências sonoras. Olhando-se para a audiodescrição sob a perspectiva que privilegia a oposição imagem dinâmica / imagem estática, pode-se dizer que no caso de imagens dinâmicas o audiodescritor/ tradutor precisa contemplar as seguintes questões: "o quê?", "quem?", "como?", "quando?" e "onde?" (VERCAUTEREN, 2007, p.142); e, no caso da AD de imagens estáticas, o audiodescritor deverá se ater à pergunta "como é o objeto?" (LIMA, 2011, s.p.).

Sendo a AD uma modalidade de tradução e a informação visual formada por diversos códigos de significação, verbais, visuais, linguísticos e sonoros, cabe ao audiodescritor/tradutor entender os significados propostos e ter como principal interesse imprimir as informações de maneira efetiva e clara. O objetivo deve estar em apoiar o texto de partida mediante as descrições (texto de chegada) para as pessoas com deficiência visual (receptores do texto de chegada) utilizando, para isso, um tipo textual com narrativas recorrentes, uso próprio (particular) de tempos verbais e elementos de coesão do mesmo modo que um léxico específico, que se propõe a resolver as necessidades tradutórias que os novos formatos de tradução exigem.

Audiodescrever é transformar todos os códigos em um meio sonoro. Logo, o público com deficiência visual receberá um texto composto somente de códigos sonoros: $\mathrm{AD}$, diálogos, música e efeitos sonoros. Portanto, a audiodescrição se encarrega de condensar a informação vinculada por códigos visuais, elaborando textos que cooperem com o restante dos códigos (PAYÁ, 2007, p.4).

Posadas (2008) aproxima a audiodescrição da linguística para comprovar sua natureza tradutória quando se baseia na definição de texto proposta por Bernárdez:

Texto é uma unidade linguística comunicativa fundamental, produto da atividade verbal humana, que tem sempre caráter social, está caracterizada por seu eixo semântico e comunicativo, assim como por sua coerência profunda e superficial, devido a sua intenção (comunicativa) do falante de criar um texto íntegro, e com sua estrutura mediante os conjuntos 
de regras: as próprias do nível textual e do sistema da língua. ${ }^{4}$ (BERNÁRDEZ, 1982, p. 85 apud POSADAS, 2008, p. 94)

Considerando leitura e texto em um sentido semiótico, o espectador também é um leitor. $\mathrm{O}$ audiodescritor, por sua vez, é o primeiro leitor, e deve observá-lo de forma crítica a ponto de conhecer os códigos pertinentes a cada gênero, visto que são esses códigos que pressupõem a gramática do seu texto de partida.

Por conta disso, o audiodescritor como produtor textual é quem responde, de forma coesa e coerente, às possíveis perguntas do receptor com deficiência visual e elabora a reconstrução comunicativa da $\mathrm{AD}$, com a intenção de apoiar as imagens com frases descritivas, descrevendo-as de maneira que o receptor entenda o código em áudio

\section{AUDIODESCRITOR: LEITOR MODELO}

O audiodescritor, por ser um tradutor, deve ser primeiramente, como propõe Umberto Eco (1979), um leitor-modelo, isto é, um leitor capaz de decodificar a intenção do texto, que faça as interpretações necessárias para o entendimento da obra analisada e posteriormente audiodescrita, para que possa, assim, transmitir as informações relevantes para o público usuário dessa técnica tradutória. Assim sendo, discorrendo sobre a audiodescrição e o papel do audiodescritor, deve-se partir do pressuposto de que "[...] um audiodescritor é um observador ativo, e por isso, é importante aprimorar seu letramento visual, olhar o mundo com maior acuidade a fim de compartilhar o que há nas imagens" (ALVES; TELES \& PEREIRA, 2011, p. 23).

O ADR precisa editar o que vê, ou seja, saber diferenciar o que é mais relevante, selecionar o que deve ser levado em consideração partindo do geral para o mais específico e utilizando uma linguagem objetiva, pois cabe a ele garantir acessibilidade, e não facilitar ou explicar a obra.

Umberto Eco que afirma que um texto postula o leitor - o leitor-modelo - como condição indispensável, não apenas da própria capacidade concreta de comunicação, mas também da sua potencialidade significativa. A discussão sobre

4. "Texto es la unidad lingüística comunicativa fundamental, producto de la actividad verbal humana, que posee siempre carácter social; está caracterizado por su cierre semántico y comunicativo, así como por su coherencia profunda y superficial, debida a la intención (comunicativa) del hablante de crear un texto íntegro, y a su estmcturación mediante dos conjuntos de reglas: las propias del nivel textual y las del sistema de la lengua." 
esse papel colaborativo aparece pela primeira vez em A obra aberta, de 1962. No entanto, é em um conjunto de ensaios que aparecem alguns dos textos mais conhecidos do autor no que se refere ao papel do leitor nos textos narrativos. A obra Lector in fabula (1983), juntamente com The role of the reader: explorations in semiotics of texts (1979), reúnem os principais textos de Eco sobre o tema.

Em seu Lector in Fabula (1983), ao analisar as possibilidades e limites da interpretação, Eco deixa clara a importância de considerar o outro, implicando um sistema dialógico em jogo, no qual o texto é incompleto e por isso precisa sempre da colaboração do destinatário.

$\mathrm{Na} \mathrm{AD}$, considerar o outro é fundamental, pois o audiodescritor tem que levar em consideração que a audiodescrição é um mecanismo de mediação concebido para que cada um possa suscitar suas próprias interpretações, cabendo ao audiodescritor ser um leitor-modelo a fim de transmitir de maneira clara as possíveis intenções do produtor audiovisual, da peça teatral, da obra de arte, das imagens e expressões gestuais em uma palestra e levar a pessoa com deficiência visual a fazer suas inferências.

Ainda segundo Eco, além de destinatário, o leitor é também co-participante do processo gerativo de um texto, pois "[...] o autor tem de prever um modelo de leitor (o leitor-modelo) supostamente capaz de interpretar o texto da mesma maneira que o autor previu durante o processo de geração deste" (ECO, 1979, p.7). ${ }^{5}$ Isso significa que o leitor-modelo funciona como agente propulsor da produção e, consequentemente, deve levantar hipóteses sobre a intenção do texto, ou seja, pode e deve fazer diversas interpretações.

A interpretação é um processo de descobertas de significados. Cada texto possui uma infinidade de caminhos interpretativos capaz de construir um leitormodelo que progride por abduções, tal qual postulado por Peirce (2012), num processo de semiose ilimitada (mas não descontrolada), seguindo a estrutura do texto percebido. Como afirma Eco,

[o] texto está, pois, entremeado de espaços brancos, de interstícios a serem preenchidos, e que o emitiu previa que esses espaços e interstícios seriam preenchidos e os deixou brancos por duas razões. Antes de tudo, porque um texto é um mecanismo preguiçoso (ou econômico) que vive da valorização de sentido que o destinatário ali introduziu (...). Em segundo lugar, porque à medida que passa da função didática para a estética, o texto quer deixar ao leitor a

5. "the author has thus to foresee a model of the possible reader (hereafter Model Reader) supposedly able to deal interpretatively with the expressions in the same way as the author deals generatively with them." 
iniciativa interpretativa, embora costume ser interpretado com uma margem de univocidade. Todo texto quer que alguém o ajude a funcionar. ${ }^{6}$ (ECO, 1983, p. 76)

Outro fator que caracteriza a maior complexidade do texto é o fato de ele ser entremeado pelo não-dito, ou seja, aquilo que se apresenta de forma implícita. Deve-se considerar, porém, que toda interpretação é feita devido, também, ao uso e destino/objetivo da obra, logo, a intenção é analisar o inconsciente do texto e não o inconsciente do autor.

O tradutor é o leitor-modelo do original, pois constrói sua própria interpretação. Assim, sendo o audiodescritor um tradutor, deve ser um leitormodelo para que possa sempre observar o que o texto tem além do que está sendo mostrado, mover o texto de modo a construí-lo e podendo assim transmitir as ideias entendidas e subentendidas para a AD. Visto que o texto prevê o leitor, então é preciso destacar a importância dos aspectos pragmáticos postos em jogo na relação texto-leitor. Deve-se considerar que a competência do destinatário não é necessariamente a do emitente, o que implica dizer que para "decodificar" uma mensagem verbal é preciso, além da competência linguística, uma competência variavelmente circunstancial, capacidade de pressupor, reprimir idiossincrasias, etc. (ECO, 1983, p. 77).

Quando se trata de interpretação sempre se exige algum limite, já que a noção de interpretação sempre envolve uma dialética entre estratégia do autor e resposta do leitor-modelo (ECO, 1983, p. 86). Eco, ancorado em Peirce, não nega que a corrente das interpretações pode ser infinita, mas alerta para a questão de que o universo do discurso intervém para restringir o formato da linguagem a ser adotada. Assim, usar livremente um texto tem a ver com a decisão de ampliar o universo do discurso. Para Eco, a interpretação pressupõe um recorte, a existência de limites determinados pelas estratégias textuais postas em jogo pela dialética autor, texto e leitor-modelo.

A despeito de todas essas cautelas, sempre haverá a dúvida quanto à possibilidade de descrever sem interpretar. Tendo como base o artigo de Hurtado (2007, p. 77) que desmitifica algumas práticas da audiodescrição - como o uso de

6. "El texto está plagado de espacios en blanco, de intersticios que hay que rellenar; quien lo emitió preveía que se los rellenaría y los dejó en blanco por dos razones. Ante todo, porque un texto es un mecanismo perezoso (o económico) que vive de la plusvalía de sentido que el destinatario introduce en él y sólo en casos de extrema pedantería, de extrema preocupación didáctica o de extrema represión el texto se complica con redundancias y especificaciones ulteriores (hasta el extremo de violar las reglas normales de conversación). En segundo lugar, porque, a medida que pasa de la función didáctica a la estética, un texto quiere dejar al lector la iniciativa interpretativa, aunque normalmente desea ser interpretado con un margen suficiente de univocidad. Un texto quiere que alguien lo ayude a funcionar". 
palavras como «veja»e «olhe», consideradas politicamente incorretas para alguns modelos, e o uso da estrutura frasal sujeito-predicado-predicativo que implicava a interpretação do ADR, isto é, em $30 \%$ dos casos (e o predicativo nesse tipo de construção implica justamente a ocorrência de interpretação) - Araújo (2010, p. 98) apresenta as seguintes ponderações:

Devemos saber que, ao fazermos uma narrativa, sempre deixamos nossas impressões e nossa visão de mundo. O audiodescritor só precisa tomar cuidado na escolha de sua adjetivação para não colocar suas inferências no texto, principalmente aquelas cruciais para o entendimento do filme. A garantia da acessibilidade reside em que a leitura do filme seja feita pelo espectador, seja ele vidente, ouvinte, surdo ou com deficiência visual. Não faz parte do trabalho do audiodescritor facilitar essa leitura. Ele precisa traduzir as imagens para propiciar à pessoa com deficiência visual a oportunidade de fazer a própria interpretação.

Levando em conta a teoria apresentada e as denominações de texto feitas por Eco (1983), deve-se ter em mente que a AD se caracteriza como um texto fechado, pois é claramente dirigida a um determinado público e possui determinados propósitos.

\section{O PROCESSO DE PRODUÇÃO DA AUDIODESCRIÇÃO SIMULTÂNEA}

Independentemente do tipo de modalidade de AD, um ADR precisa compreender como funciona todo o processo do seu trabalho. Precisa atentar para sua formação profissional e estar aberto a novas experiências e à evolução contínua do desenvolvimento da audiodescrição, conhecer os materiais e equipamentos com os quais irá trabalhar, mas também conhecer as necessidades do seu público e os processos de contratação. Como a atividade da audiodescrição ainda é um serviço considerado relativamente novo, não existem normas específicas para todas as modalidades ${ }^{7}$, e os audiodescritores podem ser obrigados a desenvolver a habilidade de lidar com bastantes incertezas no seu campo de trabalho.

$\mathrm{Na}$ ADS todas as etapas da audiodescrição ocorrem ao mesmo tempo em que a obra é exibida e o equipamento utilizado é o mesmo da tradução simultânea. Ela ocorre quando não é possível para o audiodescritor conhecimento prévio suficiente da obra a ser descrita, como nos casos de eventos ao vivo nos quais não se pode

7. Em outubro de 2016 foi lançado o Guia para Produções Audiovisuais Acessíveis, uma parceria da Secretaria do Audiovisual do Ministério da Cultura e da UnB, que traz parâmetros para a audiodescrição de cinema e TV. O Guia foi elaborado por uma equipe voluntária de professores e profissionais de diferentes regiões do Brasil. Sua distribuição é gratuita e está disponível em: https://matavunesp.files.wordpress.com/2016/10/guiaparaproducoesaudiovisuaisacessiveis2016. pdf Acesso em 05/11/2016. 
saber com antecedência o desenrolar dos fatos e, portanto, não há como se ter um roteiro fixo. $\mathrm{O}$ audiodescritor deve ter então um treinamento específico para realizar sua tarefa.

Em eventos realizados por órgãos da administração pública, as especificações para a contratação presentes nos termos de referências podem ser um importante sinal de orientação e, dada a relevância dos governos como clientes, talvez possam auxiliar o audiodescritor, com o tempo e experiência necessários, a entender seu universo.

Todavia, qualquer que seja o tipo de evento a ser audiodescrito, o ADR deve fazer um pré-roteiro com o repertório linguístico que mais se adeque à proposta da obra, bem como uma pesquisa prévia sobre o evento, a fim de conseguir o máximo de informações possíveis sobre este. Mesmo que os produtores não repassem tais informações, elas podem ser obtidas através de sites, folders e propagandas sobre o evento que será audiodescrito, e cabe ao ADR fazer essa busca para enriquecer e até facilitar seu trabalho. Tal providência é de grande valia e de suma importância para a boa execução do trabalho.

Em eventos presenciais, tais como congressos e seminários, é comum a utilização de ADS devido à presença de pessoas com deficiência, principalmente os eventos que têm a acessibilidade como foco. Assim sendo, buscaremos neste trabalho enfocar a audiodescrição simultânea para esse tipo de evento no intuito de sugerir uma metodologia que possa ser adotada pelos ADRs no Brasil e que atenda à necessidade das pessoas com deficiência visual. Como explica Motta $(\mathrm{s} / \mathrm{d})$,

Os audiodescritores ficam em cabines acústicas com um roteiro previamente elaborado sobre o local do evento, logomarcas, vídeos que serão apresentados e tudo o que é possível adiantar, como o conhecimento prévio de terminologia, nomes dos palestrantes e suas apresentações. As pessoas com deficiência visual recebem receptores e fones de ouvido e podem, dessa maneira, escutar a audiodescrição que é inserida, preferencialmente, em momentos de pausa do palestrante ou em momentos em que a sobreposição de falas não comprometa o entendimento. ${ }^{8}$

Além das questões técnicas explicitadas por Motta, os estudos de Catalina Himenez Hurtado, como Una gramática local del guión audiodescrito: Desde la semántica de un nuevo tipo de traducción (2007) e Un corpus de cine: Fundamentos teóricos de la audiodescripción (2010), têm se tornado referência para muitos ADRs, já que a autora apresenta bases epistemológicas e estruturas linguísticas (a partir da análise de corpora compostos

8. Disponível em: http://www.vercompalavras.com.br/pdf/apresentacoes-acessiveis.pdf Acesso em 05/11/2016. 
por roteiros de $\mathrm{AD}$ para cinema) que nos permitem criar uma gramática do texto audiodescrito.

Entre essas regras estão, por exemplo, o tempo verbal ou o tipo de oração que se utiliza para descrever emoções, sentimentos, ou os sintagmas mais recorrentes para descrever a localização de algo em determinado lugar ou tempo. As etiquetas, feitas no software de análise textual (Wordsmith Tool), foram organizadas hierarquicamente, das categorias mais gerais para as mais especificas, e foram sendo compostas a partir da seleção dos lexemas mais utilizados (HURTADO, 2010).

O Guia para Produções Audiovisuais Acessíveis (NAVES et alli, 2016) também traz parâmetros para a audiodescrição contemplando questões técnicas, linguísticas e tradutórias que ampliam o escopo das pesquisas de Hurtado (2010), além de contribuições para o público brasileiro, visto ser o resultado de pesquisas de recepção com esse público e podem ser utilizados como ponto de partida para outras modalidades de $\mathrm{AD}$ que não a cinematográfica, como por exemplo a descrição de personagens: "Na descrição dos atributos físicos de um personagem é recomendável a seguinte sequência: gênero, faixa etária, etnia, cor da pele, estatura, compleição física, olhos, cabelos e demais características marcantes." E figurinos: "Começar pelas peças maiores e pela parte superior para depois passar para as menores e acessórios" (NAVES et alli, 2016, p. 26-27). Também contribui para o uso da linguagem:

Usar verbos específicos que indiquem a maneira de realização das ações ex: pular, saltar, saltitar. [...] $\mathrm{O}$ uso do presente do indicativo é recomendado, pois torna o texto fluido e expressa o fato no momento em que acontece. [...]. Quanto à complexidade sintática, recomenda-se o uso de orações coordenadas, sem muita complexidade; ou períodos simples, principalmente devido ao pouco espaço entre as falas dos personagens. Evitar linguagem rebuscada, termos chulos, gírias. (NAVES et alli, 2016, p. 24-25)

Na ADS também devemos manter uma preocupação minuciosa com os elementos mais específicos da gramática do texto audiodescrito, como o vocabulário utilizado e a norma culta, apesar da rapidez e da imprevisibilidade com que as informações se apresentam para o ADR. Porém, parâmetros mais gerais podem ser mais factíveis para a composição desse tipo de AD. Vejamos a tabela abaixo: 
Tabela 2. Parâmetros gerais de análise para audiodescrição

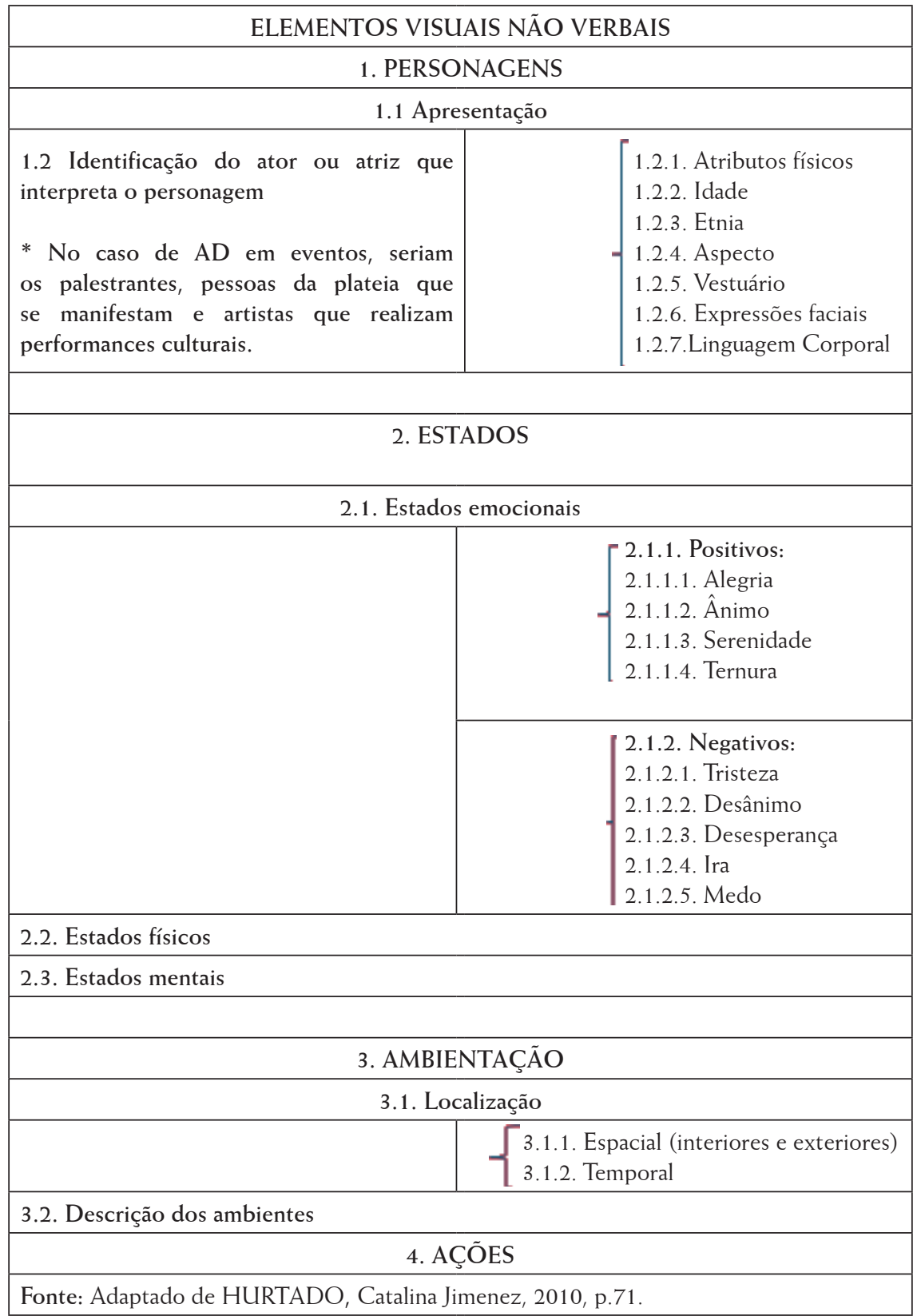


Os parâmetros de Jimenez Hurtado e os do Guia para Produções Audiovisuais Acessíveis serviram como norteadores para o modelo que propomos aqui. Porém, os estados das pessoas/personagens, sejam eles emocionais ou mentais, não consistem em informações prioritárias na ADS como no cinema, por exemplo, visto que, o que de fato é priorizado na audiodescrição simultânea é a localização espacial e temporal do evento, bem como a descrição dos ambientes.

\section{PROPOSTA DE METODOLOGIA PARA ADS}

Para a ADS, propomos primeiro a apresentação do ADR, depois a descrição da ambientação e das pessoas que se apresentam no palco.

Devido ao tempo de que os audiodescritores dispoem para fazer seu trabalho ao vivo, é importante ambientar o público, logo no início do evento, mesmo antes do início dos trabalhos, quanto ao lugar em que ele está, o logo do evento, os painéis temáticos, a composição do palco e a movimentação da plateia. Para tal, o ADR deve visitar o local, se possível, um dia antes, ou chegar com no mínimo uma hora e trinta minutos de antecedência para testar o equipamento e escrever o préroteiro que poderá ser lido para os usuários enquanto aguardam o início do evento ou em intervalos.

Propomos, a seguir, um modelo de pré-roteiro, que segue em partes os elementos propostos por Hurtado (2010) e pelo Guia para Produções Audiovisuais Acessíveis (2016): 


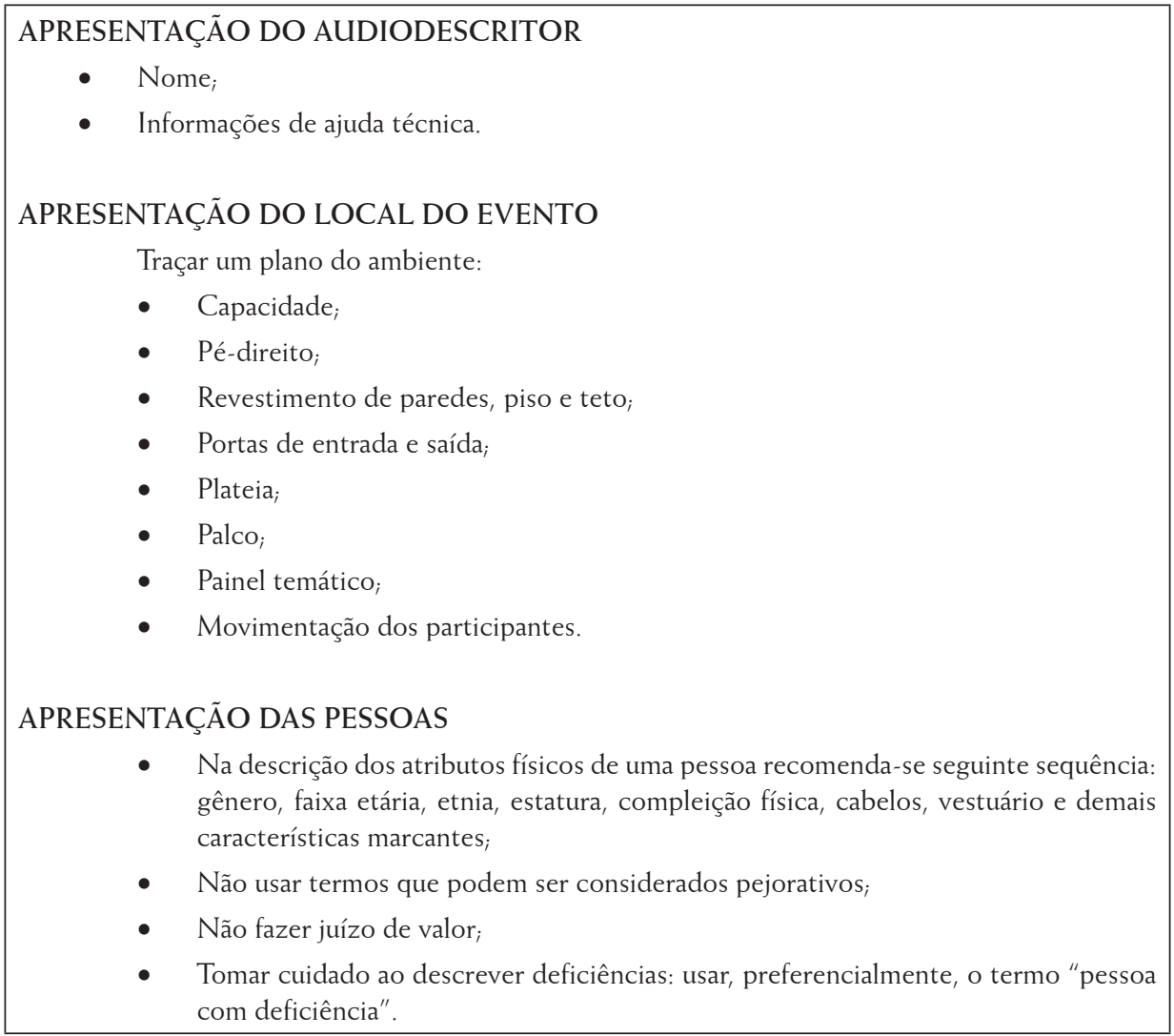

O modelo proposto foi baseado nas experiências das autoras e em pesquisas realizadas no âmbito do Grupo de Pesquisa e Extensão Acesso Livre, da Universidade de Brasília - UnB.

No referido grupo, desde seu início em 2010 e a partir do envolvimento de três professores do Departamento de Línguas Estrangeiras e Tradução (Prof. Chares Rocha Teixeira, Prof. Helena Santiago Vigata e Soraya Ferreira Alves foram desenvolvidas pesquisas em nível de doutorado e pós-doutorado, tanto com base na recepção da audiodescrição por pessoas com deficiência, como também na formação de audiodescritores. A autora Veryanne CoutoTeles também desenvolveu sua dissertação de mestrado sobre audiodescrição para cinema a partir de pesquisas de recepção iniciadas no Grupo Acesso Livre; e de Especialização, sobre audiodescrição simultânea, na Universidade Federal de Juiz de Fora - UFJF, a partir de treinamento e atuação profissional advindas também de iniciativas desse mesmo Grupo. 
Nossas pesquisas foram, em um primeiro momento, norteadas pela bibliografia internacional, mas há muito vêm se fundamentando em bibliografia nacional, tendo como base relevante nossa própria produção. Além das pesquisas individuais, foram desenvolvidas pesquisas teóricas e metodológicas aplicadas à prática da audiodescrição, o que nos dá uma vertente prática e social, permitindo a aplicação de nossas pesquisas, junto com alunos com e sem deficiência visual, a situações reais envolvendo usuários da audiodescrição. Uma vez que a audiodescrição é um recurso de acessibilidade, a observação de sua eficiência junto a seus usuários é fundamental para correções e redimensionamentos.

Daremos, a seguir, exemplo de pré-roteiro realizado na Segunda Conferência Nacional de Proteção e Defesa Civil, realizada de 4 a 7 de novembro de 2014, no Centro Internacional de Convenções do Brasil, em Brasília. Seguem também as imagens do painel temático e do ambiente para ilustração do roteiro.

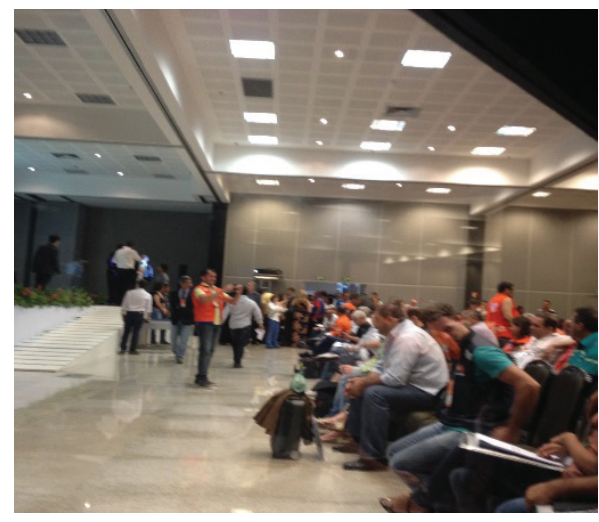

Fig. 1

(Fonte: Página do evento. Disponível em: http://www.2cnpdc.mi.gov.br/pt/)

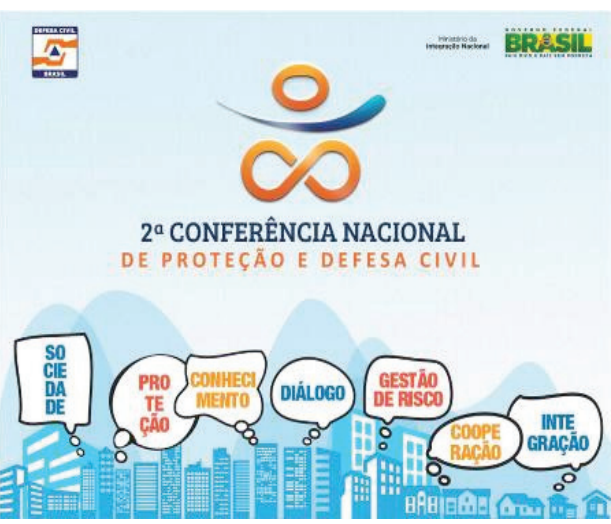

Fig. 2

(Fonte: Arquivo pessoal das autoras)

Bom dia, meu nome é ......... e serei sua audiodescritora durante este evento.

Se bouver qualquer problema com o equipamento de audiodescrição, receptores e fones de ouvido, favor levantar o braço para que seja feita a troca ou levá-lo até o local de retirada.

O ambiente em que nos encontramos é bastante amplo, com capacidade para quinbentas pessoas. Está bem iluminado. O pé direito tem aproximadamente 6 metros. As paredes são revestidas de tecido cinza claro, o piso é de granito, mesclado de bege claro e cinza. O teto é branco.

As 3 portas de entrada e saída do salão encontram-se à direita.

As cadeiras da plateia são revestidas de tecido marrom claro salpicado de marrom escuro. Os pés são pretos. 
À frente da plateia está o palco, elevado a meio metro do chão. Ele é todo branco e ocupa toda a extensão da sala, a não ser por um pequeno espaço à direita, onde está localizada a mesa de som. Do lado direito bá uma pequena escada de 4 degraus e uma rampa de acesso. Próximo à rampa encontra-se um púlpito, de acrilico transparente.

Toda a frente do palco é margeada por um canteiro de follhagens verdes e flores exóticas vermelhas, tais como bromélias, com pétalas grandes e duras. Em cima do palco bá 8 poltronas brancas com pés cromados, entremeadas por mesinhas brancas com tampo de vidro, sobre as quais encontram-se copos e garrafas de água.

Atrás das poltronas, preso à parede do fundo do salão, o painel temático do evento: sobre fundo azul claro, na parte superior, o logo, formado por um 8 deitado na cor laranja. Sobre este, um círculo também na cor laranja. Entre os dois, bá um traço azul, que se assemelha a uma pincelada. Do lado direito, também na parte superior, o logo da Defesa Civil: um quadrado com moldura azul escuro e no centro o desenho estilizado de duas mãos em concha, uma sobre a outra, como se segurassem e protegessem um pequeno triângulo laranja. Do lado esquerdo, o logo do governo federal: a palavra Brasil em verde, sobre faixa amarela. Sobre o A central, o losango amarelo sobreposto por esfera azul cortada por faixa branca, como na bandeira brasileira. Acima, o letreiro: Governo Federal, e abaixo, país rico é país sem pobreza. Abaixo do logo, o letreiro: Segunda Conferenncia Nacional de Proteção e Defesa Civil, em laranja e azul.

$\mathrm{Na}$ parte inferior, abaixo do letreiro, bá o desenho de uma cadeia de montanbas e, na frente desta, o traçado de vários prédios e casas, dos quais surgem balóes de diálogos, como nos quadrinbos, com as palavras: sociedade, proteção, conbecimento, diálogo, gestão de risco, cooperação, integração.

Do lado esquerdo do painel estão enfileiradas as bandeiras do Brasil e dos estados brasileiros. Dos dois lados do palco, bá telões.

No momento, a plateia já tem mais da metade de sua capacidade ocupada. Muitas pessoas entram no salão e tomam seus lugares. Há várias pessoas em pé, grupos se confraternizam, tiram fotos próximos ao palco.

Nas duas primeiras filas da plateia, reservadas para as pessoas bomenageadas que receberão a insígnia de comendador, já bá várias delas sentadas. Alguns senhores usam uniformes das forças armadas brasileiras, branco da marinha, verde do exército e cinza azulado da aeronántica. Os paletós têm botões dourados, medalhas, condecorações e patentes. Outros senhores usam ternos escuros. As mulheres usam trajes elegantes, bem cortados e de cores variadas. Estão bem penteadas e maquiadas. Os delegados usam os coletes laranja da defesa civil sobre suas roupas.

Sobre o palco, agora, o mestre de cerimônia. Ele tem aproximadamente 30 anos, é branco, alto, magro, tem cabelos escuros e curtos. Veste terno cinza claro com camisa branca e gravata azul. É ele quem fala...

Durante um evento também podem acontecer apresentações artísticas e, nesse caso, as descrições podem ter um caráter também artístico, dando informações 
mais detalhadas sobre ações, vestuário e estado emocional, como no exemplo abaixo, que mostra a apresentação do grupo Batalá durante a CONAE (Convenção Nacional de Educação) em 2014 e a audiodescrição da cena:

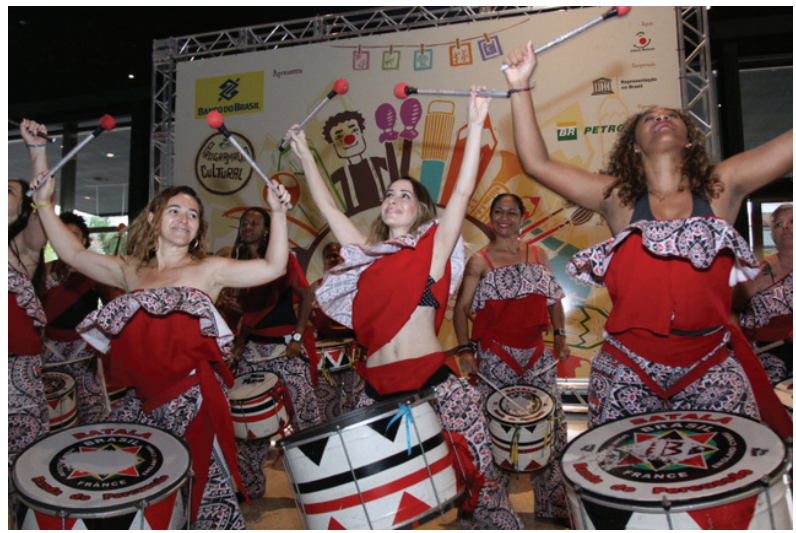

Fig. 3

(Fonte: página da CONAE 2014. Disponível em: http://conae2014.mec.gov.br/)

O grupo Batalá é composto de mulheres de diferentes faixas etárias e etnias. Vestem saia comprida e rodada na cor branca com estampas em preto e blusas tomara que caia vermelhas com babados da mesma estampa da saia. Trazem seus instrumentos de percussão, bumbos e repiques, presos à cintura por faixas também vermelhas. Os instrumentos têm fundo branco e nas laterais têm desenbos de triângulos e faixas nas cores vermelho e preto. A parte de cima traz o nome do grupo e um brasão nas cores vermelho, preto e verde. Todas as mulheres sorriem enquanto tocam. Erguem as baquetas $e$ as cruzam em cima da cabeça, em uma coreografia ritmada pela música. Sua alegria e sensualidade contagiam todo o ambiente.

O tom da narração pode variar de acordo com a cena, de um tom mais formal até um tom mais cadenciado, como na cena acima.

Também vale ressaltar que, sempre que houver tempo entre as falas e apresentações e a necessidade de intervenções, outros elementos visuais também são citados. Como elenca Motta (s/d), muitos recursos utilizados pelos palestrantes de um evento também devem ser audiodescritos:

As imagens estáticas como fotos, desenhos, pinturas, cartuns, tirinhas, gráficos, mapas e outras; e as imagens dinâmicas como: vídeos e animações são utilizadas não somente para ilustrar, chamar a atenção e tornar as apresentações mais atraentes, mas também para enfatizar aquilo que os palestrantes ou os professores estão apresentando, complementar o entendimento e torná-lo mais facilmente compreendido ou assimilado. Todos esses recursos visuais têm o seu 
significado e não são escolhidos aleatoriamente: daí a necessidade de traduzi-los de um meio para outro, transformando as imagens em palavras. ${ }^{9}$ (MOTTA, s/d.)

Dessa forma, é necessário que o ADR se capacite para conseguir descrever figuras e gráficos sucintamente, indicando o que representam, como, por exemplo, na audiodescrição do gráfico abaixo:

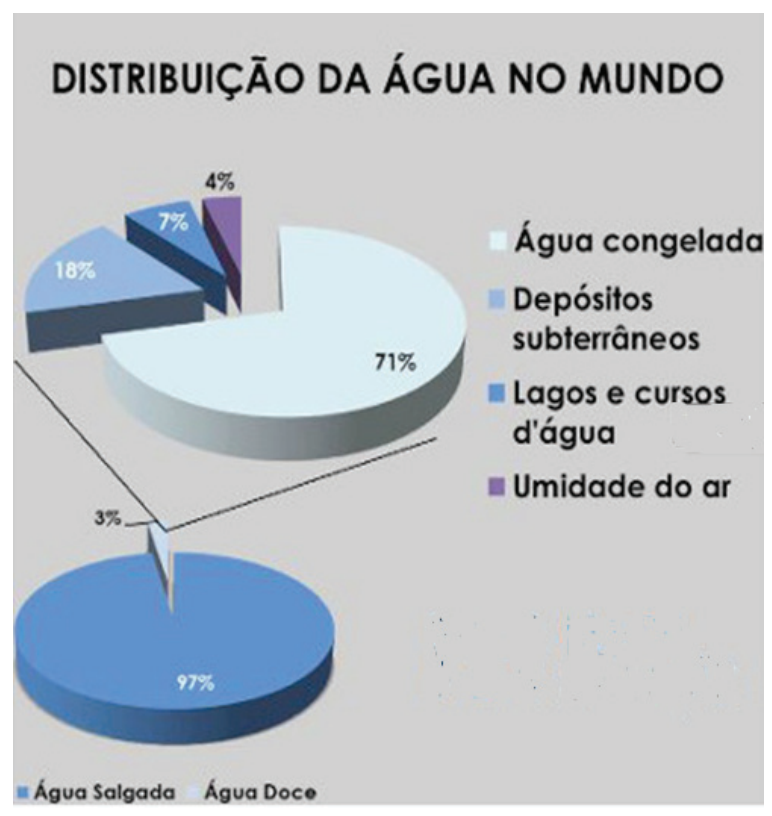

Fig. 4

Fonte: Mundo Educação. Disponível em: (http://mundoeducacao.bol.uol.com.br/geografia/ tipos-graficos.htm)

Gráfico em pizza representando a distribuição da água no mundo, sendo 97 por cento de água salgada e 3 por cento de água doce. Esses 3 por cento são compostos por 71 por cento de água congelada, 18 por cento de depósitos subterrâneos, 7 por cento de lagos e cursos d'água e 4 por cento de umidade do ar.

Muitas vezes, o próprio palestrante se refere ao significado da figura, mas outras vezes apenas aponta para ela, dizendo, por exemplo, "este gráfico traz as proporções da distribuição da água no mundo", deixando a pessoa com deficiência visual sem a informação.

9. Disponível em: http://www.vercompalavras.com.br/pdf/apresentacoes-acessiveis.pdf Acesso em 05/11/2016. 
Outros aspectos desse tipo de evento também devem ser observados e audiodescritos, como a movimentação dos apresentadores no palco, a troca de falas, gestos que indiquem significado. Por exemplo, no caso de o palestrante dizer: "Isso é o que importa", fazendo o gesto de esfregar o polegar no indicador, com o significado de dinheiro, se o ADR não audiodescrever o gesto e o que ele significa, a pessoa com deficiência visual não terá acesso à informação. Também é importante audiodescrever o que acontece na plateia, se esta se levanta e/ou senta, se há manifestações, faixas, cartazes de manifestantes etc.

Como se pode perceber, há muitas peculiaridades na audiodescrição simultânea às quais o profissional audiodescritor deve se ater. Uma má audiodescrição pode prejudicar o acompanhamento de uma palestra ou uma aula, se não trouxer os elementos para a compreensão destas. Assim, o ADR deve ter formação e treinos adequados para poder interagir com a apresentação no momento exato em que sua participação é importante e imprescindível.

\section{CONSIDERAÇÕES FINAIS}

Por se aplicar a eventos inéditos, não repetitivos, e com ritmo de informações quase sempre acelerado, a capacidade do audiodescritor de julgar suas escolhas tradutórias é, por vezes, restringida, e o pré-roteiro é uma alternativa para sistematizar o processo da ADS e tentar contribuir com a tarefa do audiodescritor.

A teoria desenvolvida nos estudos de $\mathrm{AD}$ proporciona um conjunto básico de ferramentas como recursos linguísticos e a atenção a quais detalhes devem ser relevantes para a construção das interpretações do público sobre a obra.

É preciso deixar claro, como defende Vigata (2016), que o foco na condição da pessoa com deficiência deve ser mudado, e não considerar medidas de acessibilidade como a correção de uma falta com o intuito de integrá-la na cultura visual; é preciso, contrariamente, "pensar em termos de tradução entre modos perceptivos e de construção de uma cultura multimodal onde, antes de tudo, prime o respeito e a valorização das diferenças» (p. 40).

Dessa forma, pesquisas e ações devem ser pautadas nas opiniões e consultorias das pessoas com deficiência visual para que o resultado seja eficiente e faça que se sintam confortáveis e atendidas em suas expectativas e necessidades.

O pré-roteiro proposto tentou conciliar as dificuldades vivenciadas pelas autoras, as recomendações da teoria, bem como o retorno dos usuários da audiodescrição simultânea em diversas conferências audiodescritas desde 2011, e a consultoria de alunos com deficiência participantes do nosso grupo de pesquisa e 
extensão, a fim de apontar parâmetros e métodos no que diz respeito a tomadas de decisão rápidas, porém difíceis, do audiodescritor.

Contudo, ficou claro que a prática da ADS é uma atividade em que o treinamento do audiodescritor é um fator decisivo para o êxito da audiodescrição, devido à particularidade desta modalidade e de suas escolhas tradutórias.

\section{REFERÊNCIAS BIBLIOGRÁFICAS}

ALVES, Soraya F.; TELES, Veryanne C.; PEREIRA, Tomás V. Propostas para um modelo brasileiro de audiodescrição para deficientes visuais. In: Revista Tradução e Comunicação. N. 22, 2011. Disponível em: < http://sare.unianhanguera.edu.br/index. php/rtcom/ article/view/3158>. Acesso em 05/11/2016.

ALVES, Soraya F., TEIXEIRA, Charles R. Audiodescrição para pessoas com deficiência visual: princípios sociais, técnicos e estéticos. In SANTOS; Cynthia; BESSA, Cristiane R; LAMBERTI, Flávia (org). Tradução em Contextos Especializados. Brasília: Verdana, 2015.

ARAÚJO,Vera Lúcia Santiago. A formação de audiodescritores no Ceará e em Minas Gerais: Uma proposta baseada em pesquisa acadêmica. In: MOTTA, Lívia Maria Villela de Mello e FILHO, Paulo Romeu. Audiodescrição: Transformando Imagens em Palavras. São Paulo, 2010, pp. 93-115.

BARBOSA, E. R. A transversalidade da audiodescrição no ensino de língua espanhola. In: IV Fórum Internacional de Pedagogia (FIPED), 2012, Parnaíba-PI. Anais Fiped (2012), 2012. v. 01. pp. 01-01.

CONVENÇÃO NACIONAL DA PESSOA COM DEFICIÊNCIA. Presidência da República Secretaria de Direitos Humanos. Secretaria Nacional de Promoção dos Direitos da Pessoa com Deficiência. 4a edição revista e atualizada, 2011. Disponível em <http://www.pessoacomdeficiencia.gov.br/app/sites/default/files/publicacoes/ convencaopessoascomdeficienciapdf.pdf $>$ Acesso em 03/11/2016

COSTA \& FROTA. Audiodescrição: primeiros passos. Tradução em Revista 11, 2011/2, p. 1-15. Disponível em: <http://www.maxwell.lambda.ele.puc-rio.br/trad_em_revista. php? $\operatorname{str} S e c a o=$ input0 $>$. Acesso em 05 de agosto de 2015.

DIAZ-CINTAS, Jorge. Por una preparación de calidade en accesibilidad audiovisual. TRANS-Revista de Traductologia. Universidad de Málaga, n.II. Departamento de 
Traducción y Interpretación. Servicio de Publicaciones de la Universidad de Málaga, 2007, pp. 45-99.

DIAZ-CINTAS, Jorge. Traducción Audiovisual y accessibilidad In: HURTADO, Catalina Jiménez (ed). Traducción y accessibilidad. Subtitulación para sordos y audiodescripción para ciegos: nuevas modalidades de Traducción Audiovisual. Frankfurt AM Main: Peter Lang, 2007, pp.09-23.

ECO, Umberto. The Role of the Reader: Explorations in the Semiotics of Texts. Bloomington: Indiana University Press, 1979. 284p.

ECO, Umberto. Lector in Fabula: a cooperação interativa nos textos narrativos. Tradução de Attilio Cancian. São Paulo: Perspectiva, 1983

FRANCO, Eliana; SILVA, Manoela Cristina Correia da. Audiodescrição: breve passeio histórico. In: MOTTA, Lívia Maria Villela de Mello e FILHO, Paulo Romeu. Audiodescrição: Transformando Imagens em Palavras. São Paulo, 2010, pp. 23-42.

HURTADO, Catalina Jiménez. Fundamentos teóricos de la audiodescripción. In: HURTADO, Catalina J.; RODRIGUEZ, Ana; SEIBEL, Claudia (eds.). Un corpus de cine. Teoría y práctica de la audiodescripción. Granado: Ediciones Tragacanto, 2010.

HURTADO, Catalina Jiménez. Una gramática local del guión audiodescrito. Desde la semántica de un nuevo tipo de traducción. In: HURTADO, Catalina Jiménez (ed). Traducción y accessibilidad. Subtitulación para sordos y audiodescripción para ciegos: nuevas modalidades de Traducción Audiovisual. Frankfurt AM Main: Peter Lang, 2007, pp.55-80.

JAKOBSON, R. Aspectos linguísticos da tradução. Trad. Izidoro Blikstein. In: JAKOBSON, R. Linguística e Comunicação. São Paulo: Cultrix, 1995, p.63-86.

LEI BRASILEIRA DE INCLUSÃO - LEI N 13.146, de 6 de julho de 2015. Disponível em: <http://www.planalto.gov.br/CCIVIL_03/_Ato20152018/2015/Lei/L13146. htm $>$ Acesso em 12/09/2016.

LIMA, Francisco. Áudio-descrição: arte e linguagem a serviço da pessoa com deficiência visual. Disponível em: <http://www.lerparaver.com/node/10690.> Acesso em: 25 agosto de 2013 .

MOTTA, Livia Maria V. M. Apresentações Acessíveis. Disponível em: http://www.vercompalavras. com.br/pdf/apresentacoes-acessiveis.pdf. Acesso em 12/09/2016 
NAVES, Sylvia Bahiense; MAUCH, Carla; ALVES, Soraya Ferreira; ARAÚJO, Vera Lúcia S. Guia para Produções Audiovisuais Acessíveis. Brasília: Ministério da Cultura, 2016.

PAYÁ, Maria Pérez. La audiodescripción: traduciendo el lenguaje de las cámaras. In: HURTADO, Catalina Jiménez (ed). Traducción y accessibilidad. Frankfurt: Peter Lang, 2007.

PEIRCE, Charles Sanders. Semiótica. Tradução de José Teixeira Coelho Neto. São Paulo: Perspectiva, $4^{\mathrm{a}}$ ed. 2012.

PLAZA, Julio. Tradução Intersemiótica. SP: Perspectiva, 1987

POSADAS, Gala Rodríguez. La audiodescripción: parámetros de cohesión. In: JIMÉNEZ HURTADO, Catalina (ed.). Traducción y accesibilidad: Subtitulación para sordos y audiodescripción para ciegos; nuevas modalidades de Traducción Audiovisual. 2008, pp. 93-109.

PROJETO DE LEI n ${ }^{\circ} 5.156$ de 2013, artigo1 ${ }^{\circ}$, Parágrafo único. Disponível em:<http:// www2.camara.leg.br/proposicoesWeb/prop_mostrarintegra $;$ jsessionid=D02F497E D7908A6EE5955C7E0E6D41A1.node1 codteor $=1073586 \&$ filename $=$ Avulso + PL+5156/2013 > . Acessado em 05 de agosto de 2015.

SASSAKI, Romeu Kazumi. Inclusão: acessibilidade no lazer, trabalho e educação. Revista Nacional de Reabilitação (Reação), São Paulo, Ano XII, mar./abr. 2009, pp. 10-16.

VERCAUTEREN, Gert. Towwards na European Guideline for audio description: a comparative analysis. In: DIAZ-CINTAS, Jorge; ORERO, Pilar; REMAEL, Aline (org.). Media for all: subtitling for the deaf, audio description and sign language. Amsterdam: Rodopi, 2007, pp.139-149.

VIGATA, Helena S. A experiência artística das pessoas com deficiência visual em museus, teatros e cinemas: uma análise pragmaticista. Tese apresentada ao Programa de Pós-Graduação em Comunicação da Universidade de Brasília/UnB, 2016

VIGOTSKY, L.S. A formação social da mente: o desenvolvimento dos processos psicológicos superiores. São Paulo: Martins Fontes, 1989.

VIGOTSKY, L.S. Fundamentos de defectologia. La Habana: Pueblo y Educación, 1995. (Obras escogidas, tomo V.).

Recebido: 04/11/2016

Aceito: 01/08/2017 